\title{
The Impact of Hong Kong, Macao and Taiwan Investment on Enterprise Innovation in the Pearl River Delta Region
}

\author{
Xing Li \\ College of Economics, Jinan University, Guangzhou, China \\ Email: jinanxingli@163.com
}

How to cite this paper: Li, X. (2020). The Impact of Hong Kong, Macao and Taiwan Investment on Enterprise Innovation in the Pearl River Delta Region. Open Journal of Social Sciences, 8, 87-102.

https://doi.org/10.4236/jss.2020.83009

Received: February 10, 2020

Accepted: March 7, 2020

Published: March 10, 2020

Copyright $(2020$ by author(s) and Scientific Research Publishing Inc. This work is licensed under the Creative Commons Attribution International License (CC BY 4.0).

http://creativecommons.org/licenses/by/4.0/

\section{(c) (i) Open Access}

\begin{abstract}
Based on the micro-enterprise data of the nine cities in the PRD in the database of China's industrial enterprises from 1998 to 2007, from two aspects of innovation input and innovation output, this article analyzes the impact of Hong Kong, Macao and Taiwan capital entering the Pearl River Delta region on the innovation capabilities of enterprises in the region. The empirical results show that at the enterprise level, the company's $\mathrm{R} \& \mathrm{D}$ investment and new product output decrease with the increase of Hong Kong, Macao and Taiwan capital entry. At the industry level, the deeper the entry of Hong Kong, Macao and Taiwan-funded industries, the stronger the inhibitory effect on corporate $\mathrm{R} \& \mathrm{D}$ investment and new product output. Combining the results of these two aspects, the estimation results of this article show that the entry of Hong Kong, Macao and Taiwan capital into the Pearl River Delta region has a negative effect on the innovation ability of enterprises.
\end{abstract}

\section{Keywords}

Pearl River Delta, Enterprise Level, Industry Level, Hong Kong, Macao and Taiwan Capital, Innovation

\section{Introduction}

Innovation ability is an important source and driving force for determining whether a country or region can achieve technological progress, industrial structure upgrade, and economic growth is an indispensable condition for achieving sustainable development. The theory of technology spillovers believes that FDI can directly or indirectly bring technological transfer to host country enterprises. Will the entry of foreign capital have a positive impact on the innovation capa- 
bilities of host country enterprises? Existing literature generally has three different views on this issue: "promotion theory", "inhibition theory" and "threshold effect theory". However, due to the process of marketization and system reform in various regions, the basis of regional economic development and the environment for scientific and technological progress, and the amount and quality of FDI utilization in different regions are different, and these differences affect the motivation and ability of local economic entities to absorb FDI technology spillovers. So there are regional differences in the impact of foreign investment on technological innovation capabilities (Li \& Zhang, 2008), we need to carry out specific analysis for different regions. Luo \& Ge (2015) also believed that the impact of foreign capital entry on the independent research and development of enterprises in the region should be analyzed according to the specific economic environment. Therefore, this article selects the Pearl River Delta region, where foreign capital is abundant, and studies the impact of Hong Kong, Macao and Taiwan foreign investment on the innovation of enterprises in the region.

China's Pearl River Delta region is a key area for foreign direct investment. This region attracts a large number of foreign direct investments with low labor costs and preferential tax policies. From 1979 to 2016, the actual use of foreign direct investment in Guangdong Province amounted to US \$40.85 million, US \$255.29 million in Hong Kong capital, US \$818.34 million in Taiwan capital, and US $\$ 8.65$ million in Taiwan capital. The proportion of Hong Kong, Macao and Taiwan capital in foreign investment rose from $67 \%$ in 2000 to $77 \%$ in 2016 . The proportion of foreign direct investment in the Pearl River Delta in Hong Kong, Macao and Taiwan is higher than that in non-Hong Kong, Macao and Taiwan. Here we want to explain some concepts. Generally speaking, "foreign direct investment (FDI)" generally includes two types: "foreign investment" and "Hong Kong, Macao and Taiwan investment". The former refers to Chinese-foreign joint ventures, cooperation, and wholly foreign-owned enterprises, but Excluding enterprises invested by overseas Chinese and Hong Kong, Macao and Taiwan, also known as "foreign-funded enterprises"; the latter refers to joint ventures, cooperation and wholly-owned enterprises invested by Hong Kong, Macao, Taiwan and overseas Chinese, also known as "Hong Kong, Macao and Taiwan foreign-funded enterprises". Due to their habit, they are generally referred to as "foreign investment" (Wang \& $\mathrm{Li}, 2003$ ). When analyzing the impact of foreign investment on the innovation ability of enterprises in existing literature studies, they often focus on analyzing foreign investment, such as Luo \& Ge (2015), Wu (2012), Wang et al. (2006). When analyzing the impact of foreign investment on China's innovation capacity, Hong Kong, Macao and Taiwan investment was not included in the foreign investment, or Hong Kong, Macao and Taiwan investment was not analyzed separately. However, in the Pearl River Delta region, the cumulative total investment of Hong Kong, Macao and Taiwan capital is greater than foreign investment. In the face of this regional feature, this 
article focuses on whether the entry of Hong Kong, Macao and Taiwan capital into the Pearl River Delta region will help strengthen the Pearl River Delta on the independent innovation capabilities of enterprises.

The rest of the paper is arranged as follows: the second part reviews and summarizes the relevant literature; the third part is data description and the definition of variables; the fourth part is model setting and empirical analysis; the fifth part summarizes the full text.

\section{Literature Review}

The research in this paper is mainly related to two literatures, one is the literature on the factors that affect the innovation ability of enterprises, and the other is the literature about how foreign direct investment affects the innovation of enterprises. Summarizing previous research, we can divide the factors affecting corporate innovation into two major categories: First, the company's own characteristic variables, including enterprise size, financing constraints, capital intensity, per capita wages, human capital, ownership factors, and the degree of foreign ownership etc.; Second, external environmental variables, including exports, environmental factors of external demand, market competition, government contact factors, etc. (Zhang et al., 2007; Nie et al., 2008; Kang, 2011; Zhang et al., 2012; Wu, 2012). Among them, the impact of FDI on corporate innovation has been measured from data from different perspectives and at different levels. Generally, foreign capital entering has direct and indirect effects on the host country, among which indirect effects include competition effects, technology spillover effects, and related effects. The combined effect of these effects makes the following three views on the impact of foreign investment on domestic enterprise innovation.

\subsection{Promotion Theory}

Scholars who advocate that foreign capital entry will promote the independent innovation capabilities of national enterprises believe that foreign direct investment mainly promotes the improvement of technological innovation capabilities in host countries through the indirect effects of competition effects, technology spillover effects, and front-to-back industry connections. For example, Wang et al. (2006) verified that the driving force for the improvement of independent innovation capabilities of national enterprises in the host country came from the competitive effect of international capital's participation in the local market, using local panel data from 1998 to 2003. It is inevitable to increase research and development funds to improve the technological level of the enterprise. Jiang \& Xia (2005), Tong \& Yan (2005) demonstrated the conclusion that foreign capital will promote independent innovation of national enterprises from the perspective of technology spillover effects. The former takes the domestic high-tech industry as a research object, and believes that FDI will promote the R \& D activities of domestic enterprises through demonstration and imitation effects, scien- 
tific and technological personnel mobility, and personnel training. The latter uses relevant data at the inter-provincial level and takes the number of patent applications as a proxy for innovation capabilities, and concludes that foreign investment has a significant positive spillover effect on the number of patent applications in China. Zhang (2008) also verified that foreign capital has a significant spillover effect on the independent innovation output of Chinese enterprises from the perspective of innovation input and innovation output. On the other hand, Qiu et al. (2008) and Wang et al. (2010b) etc. have verified the independent innovation effect of foreign capital on enterprises in the host country based on the perspective of industrial association. Qiu et al. (2008) obtained from the panel data of the manufacturing industry: FDI's promotion of domestic enterprises' innovation ability is more brought by backward linkage. However, Wang et al. (2010b) believed that the technological externalities formed by FDI through the forward linkage of the industry are conducive to improving the innovation efficiency of downstream domestic-funded enterprises.

The above literature is based on empirical analysis using macro-statistical caliber data, and most of them have obtained optimistic conclusions between foreign investment and corporate innovation. Turning the perspective to the micro level may lead to different conclusions. Du \& Li (2016) use panel data at the enterprise level, and the research results show that foreign investment entered in general and through mergers and acquisitions will promote domestic companies' technological research and development and product innovation. The promotion of R \& D innovation has been significantly reduced. Guadalupe et al. (2012) used data from Spanish manufacturing companies from 1990 to 2006 and found that domestic companies acquired by multinational companies can take advantage of the lower innovation costs of multinational companies to increase their innovation activities. However, some literatures have used microdata to conclude that FDI can inhibit the innovation capabilities of domestic enterprises.

\subsection{Inhibition Theory}

Fan et al. (2008) subdivided the foreign capital stocks of enterprises and industries, and found that the net effect of foreign direct investment on domestic R \& D investment was negative. Xing \& Zhang (2009) found that the technology spillover effect of foreign direct investment did not have a significant promotion effect on China's R \& D. The competition effect of FDI showed a significant promotion or inhibition effect in the short term, and the long-term effect was not significant, also supports the theory of inhibition. Wang et al. (2010a) used the panel data of Chinese enterprises and the Probit random effects model. As a result, they did not find empirical evidence that foreign direct investment as a technology transfer method significantly promoted corporate technology innovation. On the contrary, excessive reliance on foreign investment will inhibit the accumulation of local enterprises' own capabilities and curb their independent innovation activities. Luo \& Ge (2015) Using the data of China's manufacturing enterprises' R 
\& D expenditure from 2005 to 2007, from the two dimensions of the proportion of enterprises participating in independent research and development and the intensity of independent research and development, investigated the impact of the entry of multinational companies on China's independent research and development, it was found that both the proportion of independent $\mathrm{R} \& \mathrm{D}$ companies and the intensity of independent $\mathrm{R} \& \mathrm{D}$ tended to decline due to the entry of multinational companies.

\subsection{Threshold Effect}

Wang \& Zhang (2012) concluded that FDI has no obvious effect on the technological progress of Chinese domestic enterprises. Some scholars believe that the effect of FDI is not obvious because of the "threshold effect". For example, the economic development level of the central and western regions of China had not yet crossed the development threshold that caused foreign capital to have a significant positive spillover effect. Luo \& Chen (2014) Research shows that the impact of FDI on China's innovation capability has a double threshold effect of $\mathrm{R} \& \mathrm{D}$ investment and a double threshold effect of R \& D labor input. In provinces with low $\mathrm{R} \& \mathrm{D}$ investment and low $\mathrm{R} \& \mathrm{D}$ labor input, The innovation ability has a negative impact; in the provinces with medium $\mathrm{R} \& \mathrm{D}$ investment and medium R \& D labor input, FDI has a small positive impact on innovation ability; in the provinces with high $\mathrm{R} \& \mathrm{D}$ investment and high $\mathrm{R}$ \& D labor investment, FDI will significantly promote the innovation ability improve.

The existing literature also mentions the impact of Hong Kong, Macao and Taiwan capital on the innovation capabilities of domestic enterprises, and different conclusions have been reached. Such as, Zhang et al. used the cross-section data of large industrial enterprises in China in 1995 and found that the innovation efficiency of Hong Kong, Macao and Taiwan-funded enterprises was second only to foreign-funded enterprises. Nie et al. (2008) concluded that the effect of Hong Kong, Macao and Taiwan capital on corporate innovation was significantly negative. It thought that it may be due to the fact that Hong Kong, Macao and Taiwan capital entering the coastal areas of the mainland of the motherland are mostly "three to one supplement" enterprises, or foundry enterprises, and these enterprises rarely engage in research and development. Luo \& Ge (2015) also pointed out that the impact of Hong Kong, Macao and Taiwan capital on the innovation effect of Chinese enterprises is negative. However, most of these studies focus on foreign investment based on non-Hong Kong, Macao and Taiwan, and lack of specific analysis of Hong Kong, Macao and Taiwan investment and the Pearl River Delta region, especially lack of empirical analysis based on industry and enterprise-level micro-data. This article is different from the existing literature research perspective. This paper uses the micro-enterprise data of the Pearl River Delta, combined with the economic characteristics of the richness of Hong Kong, Macao and Taiwan capital in the Pearl River Delta, to ana- 
lyze the impact of the entry of Hong Kong, Macao and Taiwan capital on the innovation ability of the manufacturing enterprises in the Pearl River Delta.

\section{Model and Data Description}

\subsection{Model}

We use the following equation to estimate the impact of the entry of Hong Kong, Macao and Taiwan capital on the innovation of enterprises in the Pearl River Delta region. The model constructed in this paper is as follows:

$$
\begin{aligned}
Y_{f i t}= & \partial_{0}+\partial_{1} \text { FDI_Firm } \\
& +\beta X_{i t}+\gamma_{2} \text { Sector }+\gamma_{2} \text { City }+\gamma_{3} \text { Year }+\varepsilon_{i j t} \\
X= & \beta_{1} \text { EXP }_{i t}+\beta_{2} \text { KLD }_{i t}+\beta_{3} \text { Scale }_{i t}+\beta_{4} \text { AWage }_{i t}+\beta_{5} \text { HCapital }_{i t}+\beta_{6} \text { Loan }_{i t} \\
& +\beta_{7} \text { Profit }_{i t}+\beta_{8} \text { Age }_{i t}
\end{aligned}
$$

In the above formula, $Y$ is an index reflecting the independent innovation of the enterprise; $\varepsilon$ is a random error term. HMT_Firm ${ }_{i t}$ and HMT_Sector ${ }_{i t}$ is the natural logarithm of Hong Kong, Macao and Taiwanese investment in enterprise $i$ and industry $j$, respectively. Because company-level FDI and industry-level FDI have a cross-complementarity to improve a company's R \& D efficiency (Fan et al., 2008), this article adds HMT_Firm ${ }_{i t}^{*}$ HMT_Sector $_{i t}$ interac- $^{-}$ tion terms to the model to test how the impact of Hong Kong, Macao and Taiwanese direct investment on enterprises at the industry level varies with the degree of participation of different enterprises in Hong Kong, Macao and Taiwan. X represents the set of control variables for the characteristics of the enterprise. Sector, city and year represent dummy variables of industry, city, and year, which are used to control the differences between different industries, cities, and years.

\subsection{Data}

The data in this article comes from the database of China's industrial enterprises above designated size from 1998 to 2007, which is widely used by economists. As in the existing literature, when processing data, refer to the data processing method of Brandt et al. (2012) to match the original data and delete error records that do not conform to the basic logical relationship. such as: 1) Key indicators are missing; 2) The main business income is less than 5 million RMB, the number of employees is less than 8 or the R \& D expenditure is negative; 3 ) The total assets are less than the total of current assets, the total of fixed assets, and the average annual balance of fixed assets. In addition, according to the research purpose of this article, the cities are coded into the cities of Guangzhou, Shenzhen, Zhuhai, Foshan, Jiangmen, Zhaoqing, Huizhou, and Zhongshan, represented by $4401,4403,4404,4406,4407,4412,4413,4419$, and 4420 . The enterprise data is extracted to form the enterprise data set of the nine cities in the Pearl River Delta. Then it analyzes the impact of Hong Kong, Macao and Taiwan capital entering the Pearl River Delta on the innovation capabilities of enterprises in the 
region.

\subsection{Variable Definitions}

Most literatures mainly select the indicators of enterprise R \& D investment, new product output, and the number of enterprise patents when selecting enterprise innovation indicators. Since the data of the number of patents of enterprises in the database of Chinese industrial enterprises is not available, this article uses the two indicators of "research and development expenditure" and "new product output value" in the database to measure corporate innovation. Drawing on the practices of Nie et al. (2008), Kang (2011) and others, in order to more fully reflect the innovation situation of enterprises, we adopt two different ways to reflect the independent innovation of enterprises. One is the innovation decision of the enterprise, which is represented by dummy variables. It takes a value of 1 when its new product output is greater than zero, a value of 0 in other cases, a value of 1 when its $R \& D$ expenditure is greater than zero, and a value of 0 in other cases; the other is innovation density, which takes the output value of new products/total industrial output value as a proxy variable for measuring innovation output, and uses R \& D investment/sales as a proxy variable for measuring innovation input.

The main explanatory variables of this article are the share of Hong Kong, Macao and Taiwan investment in enterprises (HMT_Firm) and the share of Hong Kong, Macao and Taiwan investment in industries (HMT_Sector). Enterprise Hong Kong, Macao and Taiwan Investment Shares (HMT_Firm): It indicates the degree of entry of Hong Kong, Macao and Taiwan investment at the enterprise level. This article uses the proportion of Hong Kong, Macao and Taiwan capital in the paid-in capital of the enterprise to measure the Hong Kong, Macao and Taiwan investment of the company. It is used to measure the direct impact of the entry of Hong Kong, Macao and Taiwan capital on the innovation ability of enterprises in the Pearl River Delta region. Industry Hong Kong, Macao and Taiwan Investment Shares (HMT_Sector): It indicates the degree of entry of Hong Kong, Macao and Taiwan investment in a certain industry in a certain period. This article draws on the practices of Javorcik \& Smarzynska (2004), Liu et al. (2018), and takes the sales of the enterprise as a weight to weight the average share of Hong Kong, Macao and Taiwan capital of all enterprises in the industry, and then obtains the weighted average industry Hong Kong and Macau. Taiwanese capital share, the specific expression is as follows:

$$
\text { FDI_Sector }_{i t}=\frac{\sum_{f \in \Delta i t}\left(\text { FDI_Firm }_{f i t} \times \text { Sale }_{f i t}\right)}{\sum_{f \in \Delta i t} \text { Sale }_{f i t}}
$$

$\Delta i t$ Represents the set of all enterprises $t$ in the industry $i$ during the period; it is the proportion of Hong Kong, Macao and Taiwan capital to the paid-in capital of enterprises $f$ in the industry $i$ during the period $t ; S \operatorname{Sale}_{f i}$ is the sales of company $f$ in industry $i$ at time $t$. 
In addition, according to the existing theoretical and empirical research literature, this article also introduces some other factors that may have an impact on the innovation capability of enterprises, including: export intensity (EXP), capital intensity (KLD), enterprise scale (Scale), Per capita wages (AWage), human capital (HCapital), financing constraints (Loan), corporate profit margin (Profit), Corporate age (Age). Our definition of variables is as follows:

Export Intensity (EXP): The ratio of the company's export delivery value to the total industrial output value is taken as a logarithmic measure. Exports can promote domestic enterprise $\mathrm{R} \& \mathrm{D}$ through economies of scale, competition effects, and "export secondary school" effects; Capital Intensity (KLD): It is expressed by the ratio of the net value of fixed assets to the number of employees in the enterprise and taking the logarithm. Compared with labor-intensive enterprises, capital-intensive enterprises may pay more attention to their $\mathrm{R} \& \mathrm{D}$ investment; Enterprise scale (Scale): This article uses the logarithm of the company's sales to measure the size of the company. The ratio of sales to production factors is neutral and can reflect changes in short-term demand. It is considered the best proxy variable for the size of the company; Per capita wage (AWage): The ratio of the sum of the total wages and benefits of an enterprise to the number of employees in the enterprise. Enterprises tend to attract outstanding talents by providing higher wages and benefits, and employees with higher levels of knowledge and skills will undoubtedly play a greater role in promoting innovation; Human Capital (HCapital): this article uses the per capita education and training costs of the company as a proxy for measuring the human capital of the company. The companies with more human capital are more inclined to conduct R \& D activities; Financing constraints (Loan): Measured by the ratio of interest expenditure to fixed assets to reflect the external financial environment facing the company and its ability to obtain external credit financing (Zhang et al., 2012); Corporate profit margin (Profit): The ratio of operating profit to corporate sales. Profit margin is the root of corporate survival, production behavior and innovation activities. The higher the corporate profit margin, the more capable the company is in R \& D (Liu et al., 2018); Age of the enterprise (Age): Measured by the difference between the year of the current year and the year in which the company opened.

In the regression of this paper, the natural logarithm is adopted to reduce the sample loss caused by some variables being zero. Table 1 gives definitions and simple statistical descriptions of all variables.

\section{Regression Results}

\subsection{Basic Regression Analysis}

Due to whether there is a binary selection variable for $\mathrm{R} \& \mathrm{D}$ investment and new product output, and there is a clear cross-section of innovation density, there are a large number of enterprises' $\mathrm{R} \& \mathrm{D}$ investment and new product 
Table 1. Variables and definition.

\begin{tabular}{|c|c|}
\hline Variable & Definition \\
\hline Innovation decision & $\begin{array}{l}\text { a value of } 1 \text { when the output of the new product is greater than zero, } \\
\text { otherwise } 0\end{array}$ \\
\hline \multirow{3}{*}{ Innovation density } & $\begin{array}{l}\text { a value of } 1 \text { when its } \mathrm{R} \& \mathrm{D} \text { expenditure is greater than zero, } \\
\text { otherwise } 0\end{array}$ \\
\hline & Ln (the output value of new products/total industrial output value +1 ) \\
\hline & Ln $(\mathrm{R} \& \mathrm{D}$ investment/sales +1$)$ \\
\hline HMT_Firm & Ln (Hong Kong, Macao and Taiwan Capital/Paid-in Capital + 1) \\
\hline HMT_Sector & $\begin{array}{l}\text { Ln (Entry indicators for Hong Kong, Macao and Taiwan-funded } \\
\text { industries }+1)\end{array}$ \\
\hline Export Intensity & Ln (Export Delivery Value/Industrial Sales Output Value +1 ) \\
\hline Capital Intensity & Ln (Net Fixed Assets/Employees +1 ) \\
\hline Enterprise scale & Ln (Sales) \\
\hline Per capita wage & Ln $(($ Salary + welfare expenses $) /$ number of employees +1$)$ \\
\hline Human Capital & $\operatorname{Ln}($ Staff education costs/number of employees +1$)$ \\
\hline Financing constraints & Ln (Interest expense/total assets +1 ) \\
\hline Corporate profit margin & Ln (Operating profit/sales +1$)$ \\
\hline Age of the enterprise & Ln $(($ Current year-opening year $)+1)$ \\
\hline
\end{tabular}

output value of 0 , so We choose the Probit model to estimate the impact of Hong Kong, Macao and Taiwan capital shares on corporate innovation decisions, and choose the Tobit model to estimate the relationship between Hong Kong, Macao and Taiwan investment and the density of corporate innovation. The results are listed in Table 2 and Table 3, respectively. Among the estimated results, the parameters of most interest are $\partial_{1}, \partial_{2}$ and $\partial_{3}$. If $\partial_{1}$ is significantly positive, it means that the increase in the share of Hong Kong, Macao, and Taiwanese capital in the enterprise has promoted the improvement of the innovation capacity of the Pearl River Delta enterprises. On the other hand, if $\partial_{1}$ is significantly negative, the entry of Hong Kong, Macao, and Taiwanese capital in the enterprise has inhibited the innovation of the Pearl River Delta enterprises. If $\partial_{2}$ is significantly positive, it means that the increase of Hong Kong, Macao, and Taiwanese capital in the industry has promoted the improvement of the Pearl River Delta enterprises' innovation capabilities. On the other hand, if $\partial_{2}$ is significantly negative, the increase of Hong Kong, Macao, and Taiwanese capital in the industry has inhibited the innovation of the Pearl River Delta enterprises. If $\partial_{3}$ is significantly positive, the increase in direct investment by Hong Kong, Macao and Taiwan businessmen at the industry level will promote corporate innovation. On the other hand, if $\partial_{3}$ is significantly negative, the increase in direct investment by Hong Kong, Macao and Taiwan businessmen at the industry level will inhibit corporate innovation.

This article first examines the impact of corporate Hong Kong, Macao and Taiwan capital shares and industry Hong Kong, Macao and Taiwan capital 
Table 2. Regression results 1.

\begin{tabular}{|c|c|c|c|c|c|c|}
\hline \multirow[b]{2}{*}{ Variable } & \multicolumn{3}{|c|}{$\begin{array}{l}\text { Explained variable: } \\
\text { Is there a new product }\end{array}$} & \multicolumn{3}{|c|}{$\begin{array}{c}\text { Explained variable: } \\
\text { Whether independent } \mathrm{R} \& \mathrm{D}\end{array}$} \\
\hline & (1) & (2) & (3) & (4) & (5) & (6) \\
\hline \multirow[t]{2}{*}{ HMT_F } & $-0.327^{\star * *}$ & $-0.399^{* * *}$ & $-0.472^{\star * *}$ & $-0.215^{\star * *}$ & $-0.260^{\star * *}$ & $-0.228^{\star \star}$ \\
\hline & $(0.0247)$ & $(0.0329)$ & $(0.1050)$ & $(0.0226)$ & $(0.0275)$ & $(0.0937)$ \\
\hline \multirow[t]{2}{*}{ HMT_S } & $-0.958^{* * *}$ & $-0.321^{\star * \star}$ & $-0.756^{\star * *}$ & $-1.801^{\star * *}$ & $-1.104^{\star * *}$ & 0.0780 \\
\hline & $(0.0742)$ & $(0.0861)$ & $(0.2300)$ & $(0.0601)$ & $(0.0776)$ & $(0.2050)$ \\
\hline \multirow[t]{2}{*}{ FS } & & & 0.179 & & & -0.167 \\
\hline & & & $(0.2410)$ & & & $(0.2230)$ \\
\hline \multirow[t]{2}{*}{ EXP } & & $0.152^{* * *}$ & $0.0786^{\star *}$ & & $-0.102^{* * *}$ & $-0.362^{* * *}$ \\
\hline & & $(0.0294)$ & $(0.0358)$ & & $(0.0276)$ & $(0.0339)$ \\
\hline \multirow[t]{2}{*}{ KLD } & & $-0.0232^{* * *}$ & $0.0267^{* * *}$ & & $-0.0352^{\star * *}$ & 0.00991 \\
\hline & & $(0.0061)$ & $(0.0075)$ & & $(0.0058)$ & $(0.0072)$ \\
\hline \multirow[t]{2}{*}{ Scale } & & $0.144^{\star * \star}$ & $0.146^{\star * *}$ & & $0.232^{\star \star *}$ & $0.244^{* * *}$ \\
\hline & & $(0.0073)$ & $(0.0084)$ & & $(0.0063)$ & $(0.0076)$ \\
\hline \multirow[t]{2}{*}{ AWage } & & $0.138^{* * *}$ & $0.0491^{\star \star *}$ & & $0.257^{\star * *}$ & $0.174^{\star \star \star}$ \\
\hline & & $(0.0110)$ & $(0.0145)$ & & $(0.0110)$ & $(0.0134)$ \\
\hline \multirow[t]{2}{*}{ HCapital } & & $0.353^{* * *}$ & $0.474^{* * *}$ & & $0.727^{\star \star \star}$ & $0.859^{* * *}$ \\
\hline & & $(0.0332)$ & $(0.0356)$ & & $(0.0364)$ & $(0.0432)$ \\
\hline \multirow[t]{2}{*}{ Loan } & & $1.596^{* * *}$ & $1.744^{* * *}$ & & 0.0645 & $1.777^{\star *}$ \\
\hline & & $(0.4530)$ & $(0.5130)$ & & $(0.4780)$ & $(0.7440)$ \\
\hline \multirow[t]{2}{*}{ Profit } & & $-0.153^{* *}$ & $-0.179^{\star *}$ & & 0.0608 & 0.0617 \\
\hline & & $(0.0752)$ & $(0.0831)$ & & $(0.0858)$ & $(0.0825)$ \\
\hline \multirow[t]{2}{*}{ Age } & & $0.0900^{* * *}$ & $0.112^{* * *}$ & & $0.0997^{* * *}$ & $0.101^{* * *}$ \\
\hline & & $(0.0149)$ & $(0.0170)$ & & $(0.0130)$ & $(0.0151)$ \\
\hline $\begin{array}{l}\text { Sector/ } \\
\text { City/Year }\end{array}$ & $\mathrm{N}$ & $\mathrm{N}$ & $\mathrm{Y}$ & $\mathrm{N}$ & $\mathrm{N}$ & $\mathrm{Y}$ \\
\hline \multirow[t]{2}{*}{ Constant } & $-1.345^{\star * *}$ & $-3.595^{* * *}$ & $-5.058^{\star * *}$ & $-1.156^{* * *}$ & $-4.438^{\star * *}$ & $-5.694^{\star * *}$ \\
\hline & $(0.0222)$ & $(0.0827)$ & $(0.2310)$ & $(0.0172)$ & $(0.0710)$ & $(0.5980)$ \\
\hline Obs & 186,336 & 110,570 & 84,768 & 186,336 & 110,570 & 84,787 \\
\hline $\mathrm{R}^{2}$ & 0.011 & 0.052 & 0.119 & 0.021 & 0.131 & 0.212 \\
\hline
\end{tabular}

Notes: The data in parentheses are $\mathrm{t}$ statistics; $\mathrm{Y}$ and $\mathrm{N}$ represents the dummy variables of the added and un-added, respectively; ${ }^{* *},{ }^{* *}$, and ${ }^{*}$ indicate that the coefficient estimates are significant at $1 \%, 5 \%$ and $10 \%$ confidence levels, respectively; The following table is the same.

shares on innovation decisions in the PRD. First, we take the output value of the new product as the dependent variable without adding any control variables (column (1) in Table 2). The results show that the estimated coefficients of the shares of Hong Kong, Macao and Taiwan capital of enterprises and the shares of Hong Kong, Macao and Taiwan capital of industries are significantly negative. It can be seen that, without controlling other factors, as the share of Hong Kong, 
Table 3. Regression results 2 .

\begin{tabular}{ccccccc}
\hline & \multicolumn{3}{c}{ Explained variable: } & \multicolumn{3}{c}{ Explained variable: } \\
& \multicolumn{2}{c}{ New product output intensity } & \multicolumn{2}{c}{ Independent R \& D intensity } \\
\hline Variable & $(1)$ & $(2)$ & $(3)$ & $(4)$ & $(5)$ & $(6)$ \\
HMT_F & $-0.227^{* * *}$ & $-0.278^{* * *}$ & $-0.292^{* * *}$ & $-0.012^{* * *}$ & $-0.011^{* * *}$ & $-0.011^{* * *}$ \\
& $(0.0170)$ & $(0.0240)$ & $(0.0080)$ & $(0.0010)$ & $(0.0010)$ & $(0.0030)$ \\
HMT_S & $-0.620^{* * *}$ & $-0.264^{* * *}$ & $-0.469^{* * *}$ & $-0.090^{* * *}$ & $-0.047^{* * *}$ & 0.0020 \\
& $(0.0510)$ & $(0.0621)$ & $(0.0159)$ & $(0.0030)$ & $(0.0034)$ & $(0.0074)$ \\
FS & & & $0.091^{* * *}$ & & & -0.0011 \\
& & & $(0.0174)$ & & & $(0.0078)$ \\
Obs & 160,523 & 84,787 & 84,787 & 90,281 & 84,786 & 84,786 \\
$\mathrm{R}^{2}$ & 0.011 & 0.043 & 0.113 & 0.231 & $* 1.102$ & $* 2.069$ \\
\hline
\end{tabular}

Notes: The reason why the pseudo R2 exceeds 1 lies in the method of calculating the pseudo R by the Tobit command of the metrology analysis software (Stata13).

Macao and Taiwan capital in the enterprise and the share of Hong Kong, Macao and Taiwan capital in the industry increase, the possibility of independent innovation by the enterprise will be reduced. In column (2), we controlled the factors such as export intensity, capital intensity, enterprise size, per capita wages, human capital, financing constraints, corporate profitability, and corporate age. The coefficient is still significantly negative. However, compared to the results in column (1), the coefficients of the share of Hong Kong, Macao and Taiwan capital of enterprises are not much different, and the estimated coefficient of the share of Hong Kong, Macao and Taiwan capital of the industry has increased from -0.958 to -0.321 , indicating that it does not control some of the companies that affect corporate innovation Under the influence of factors, the inhibitory effect of the share of Hong Kong, Macao and Taiwan capital on the innovation output of the industry has been overestimated. By adding dummy variables of industry, city, and time, column (3) further controls the fixed differences between industries or regions and time, and adds the interaction between the Hong Kong, Macao, and Taiwan capital shares of enterprises and the Hong Kong, Macao, and Taiwan capital shares of industries. The results show that the interaction term coefficient is greater than 0 , but it is not significant. The share of Hong Kong, Macao and Taiwan capital in enterprises and the share of Hong Kong, Macao and Taiwan capital in industries are significantly less than 0 . Moreover, the coefficients of Hong Kong, Macao, and Taiwanese capital of enterprises and industries are smaller than the coefficients in column (2), which indicates that after further control, industry, city, time and other factors, the inhibitory effect of Hong Kong, Macao and Taiwanese capital on corporate innovation has increased, Product output tends to decline.

When the explanatory variable is replaced by a binary selection variable of whether the company has independent R \& D investment, the estimation results are listed in columns (4) to (6). The results show that without any control varia- 
ble (column (4)), the estimated coefficients of the shares of Hong Kong, Macao and Taiwan capital of enterprises and the shares of Hong Kong, Macao and Taiwan capital of industries are significantly negative. When controlling export intensity, capital intensity, enterprise size, per capita wages, human capital, financing constraints, corporate profitability, and corporate age (column (5)), the estimated coefficients of the Hong Kong, Macao and Taiwan capital shares of enterprises and the Hong Kong, Macao and Taiwan capital shares of industries It is still negative and not much different from the estimated coefficient in column (4). After further controlling the factors such as industry, city, time, etc., the estimated coefficient of foreign investment in enterprises is significantly less than 0, but the coefficient of Hong Kong, Macao and Taiwan investment in the industry has changed from negative to positive, but not significantly. The coefficients of the interaction terms are negative but not significant.

Table 3 repeats the analysis of Table 2 . The Tobit model is used to estimate the impact of Hong Kong, Macao, and Taiwan capital entry on the innovation density of the PRD enterprises, but the estimated results of all control variables are omitted. Columns (1) to (3) use the output density of new products (new product output/total industrial output value) as the explanatory variable, and columns (4) to (6) are independent research and development density (R \& D investment Sales) are the explanatory variables. From the regression results in Table 2 and Table 3, the impact of the entry of two types of Hong Kong, Macao, and Taiwanese capital on the innovation density of PRD enterprises is basically the same as that of their impact on corporate innovation decisions. However, as can be seen from the result in column (3), after controlling the characteristics of the enterprise and the industry, city, and time variables, the coefficient of the interaction term is significantly positive. It shows that the increase in the total amount of Hong Kong, Macao and Taiwan capital in the industry will increase enterprises' investment in technology research and development.

Table 2 and Table 3 have two important results. First, Hong Kong, Macao, and Taiwan capital at the enterprise level have a significant negative impact on the innovation of an enterprise $\left(\partial_{1}<0\right)$, and this impact is reflected in both the Probit model and the Tobit model. In other words, the more Hong Kong, Macao, and Taiwanese capital an enterprise participates in, the less input and output it has for innovation. This is most likely because Hong Kong, Macao and Taiwanese investors have better technology than the Pearl River Delta enterprises. The greater the Hong Kong, Macao and Taiwan investment participation of an enterprise, the more technology transfers from its Hong Kong, Macao, and Taiwanese business partners may reduce the need for its own technological innovation. Secondly, we also found that the correlation coefficient of the Hong Kong, Macao and Taiwanese investment share of the industry is negative and significant. Except when controlling corporate characteristics and virtual variables such as industry, city, time, etc., the impact of industry Hong Kong, Macao and Taiwan investment on corporate R \& D investment and R \& D investment decisions not obvious. In other words, the more Hong Kong, Macao, and 
Taiwanese capital participation in the industry, the greater the negative impact of Hong Kong, Macao, and Taiwanese capital on industry R \& D.

\subsection{Robustness Test}

The results of corporate $\mathrm{R} \& \mathrm{D}$ activities are often difficult to achieve immediately. There may be a long lag from the time when enterprises invest in research and development to the launch of innovative products. Therefore, many companies currently engaged in research and development activities may not be able to make breakthroughs in product innovation. Considering the lag of the influence of these factors on innovation activities and reducing Endogenous problem, all explanatory variables are lagging one period. The regression results are shown in Table 4. The estimated results of all control variables (including enterprise characteristic variables and dummy variables) are omitted from the table. The results show that the share coefficients of Hong Kong, Macao and Taiwan companies are negative and significant. The share of Hong Kong, Macao and Taiwan capital in the industry has a significant negative impact on the output of new products as an innovation proxy variable, and has no significant impact on corporate R \& D investment. The interaction terms of the Hong Kong, Macao and Taiwanese capital shares of enterprises and the Hong Kong, Macao and Taiwanese capital shares of industries are positive and significant when the new product output is used as the explanatory variable. This shows that the more Hong Kong, Macao, and Taiwanese capital participates, the greater the positive impact of Hong Kong, Macao, and Taiwanese capital on the company's new products. This may be that the large participation of Hong Kong, Macao and Taiwanese capital has provided enterprises with a potential, that is, companies can learn and imitate and update products through the spillover effects of Hong Kong, Macao and Taiwanese capital.

Table 4. Robustness analysis.

\begin{tabular}{|c|c|c|c|c|}
\hline \multirow[b]{2}{*}{ Variable } & \multicolumn{2}{|c|}{ New product output } & \multicolumn{2}{|c|}{$\mathrm{R} \& \mathrm{D}$} \\
\hline & $\begin{array}{c}\text { Is there a new } \\
\text { product }\end{array}$ & $\begin{array}{l}\text { New product } \\
\text { density }\end{array}$ & $\begin{array}{l}\text { Is there R \& D } \\
\text { investment }\end{array}$ & R \& D density \\
\hline \multirow[t]{2}{*}{ HMT_F $F_{i, t-1}$} & $-0.845^{\star * *}$ & $-0.510^{* * *}$ & $-0.615^{\star * *}$ & $-0.0272^{\star * *}$ \\
\hline & $(0.1300)$ & $(0.0089)$ & $(0.1270)$ & $(0.0048)$ \\
\hline \multirow[t]{2}{*}{ HMT_S $\mathrm{S}_{\mathrm{i}, \mathrm{t}-1}$} & $-0.605^{\star \star}$ & $-0.383^{\star * *}$ & -0.431 & $-0.0225^{\star *}$ \\
\hline & $(0.2950)$ & $(0.0182)$ & $(0.3030)$ & $(0.0110)$ \\
\hline \multirow[t]{2}{*}{$\mathrm{FS}_{\mathrm{i}, \mathrm{t}-1}$} & $0.737^{\star *}$ & $0.441^{\star * *}$ & -0.0190 & 0.00810 \\
\hline & $(0.2870)$ & $(0.0195)$ & $(0.3020)$ & $(0.0111)$ \\
\hline Obs & 65,315 & 65,449 & 54,202 & 54,201 \\
\hline $\mathrm{R}^{2}$ & 0.134 & 0.131 & 0.232 & ${ }^{\star} 1.708$ \\
\hline
\end{tabular}

Note: Estimates of other explanatory variables are omitted from the table. 


\section{Conclusion}

This article establishes a simple model, based on the micro-enterprise data of the Pearl River Delta, and analyzes empirically the role of Hong Kong, Macao and Taiwan capital entering the Pearl River Delta on the independent innovation input and output of enterprises in the region. Studies consistently show that the estimated coefficients of the Hong Kong, Macao and Taiwanese shares of enterprises are significantly negative. This means that if the proportion of Hong Kong, Macao and Taiwanese capital in the company increases, the company will reduce R \& D investment and new product output. The conclusion of this study has important implications for the adjustment of the investment promotion policy in the Pearl River Delta region.

In response to the above conclusions, this article proposes the following policy recommendations:

Firstly, Although innovation is one of the key factors in the new round of industrial structure transformation and growth mode transformation, we cannot ignore the role of Hong Kong, Macao and Taiwan capital in rapidly upgrading the technological level of the Pearl River Delta because we are worried that the entry of Hong Kong, Macao and Taiwan capital may inhibit independent innovation of enterprises. A more rational approach is to balance the impact on technology level and independent innovation when assessing the contribution of Hong Kong, Macao, and Taiwan capital to the Pearl River Delta, and consider adopting targeted methods to promote independent innovation of enterprises in order to avoid Hong Kong, Macao, and Taiwan capital's autonomy to enterprises Inhibition of innovation. Improving the financial environment to increase the availability of funds and reduce corporate financing costs, thereby optimizing corporate liquidity, will be one of the effective means to achieve this goal.

Secondly, the input of innovative manpower can significantly improve the scale and level of innovation activities of enterprises in the Pearl River Delta region. The government should further increase investment in education and increase the accumulation of knowledge in the Pearl River Delta region, lay a solid foundation for the introduction of high-level FDI enterprises. On this basis, encourage domestic-funded enterprises to attach importance to employee training, and attract talents with important skills to enter local enterprises from foreign-funded enterprises, in order to promote the improvement of local enterprises' independent innovation capabilities.

\section{Conflicts of Interest}

The author declares no conflicts of interest regarding the publication of this paper.

\section{References}

Brandt, L., Biesebroeck, J. V., \& Zhang, Y. (2012). Creative Accounting or Creative Destruction? Firm-Level Productivity Growth in Chinese Manufacturing. Journal of Development Economics, 97, 339-351. https://doi.org/10.1016/j.jdeveco.2011.02.002 
Du, W. J., \& Li, M. J. (2016). Foreign Capital Entry, Foreign Capital M \& A and Enterprise R \& D Innovation-Empirical Research Based on Microcosmic Level. World Economic Research, No. 6, 105-113 + 136.

Fan, C. Z., Hu, Y. F., \& Zheng, H. L. (2008). Theoretical and Empirical Research on the Impact of FDI on Technological Innovation of Domestic Enterprises. Economic Research, No. 1, 89-102.

Guadalupe, M., Kuzmina, O., \& Thomas, C. (2012). Innovation and Foreign Ownership. American Economic Review, 102, 3594-3627. https://doi.org/10.1257/aer.102.7.3594

Javorcik, \& Smarzynska, B. (2004). Does Foreign Direct Investment Increase the Productivity of Domestic Firms? In Search of Spillovers through Backward Linkages. American Economic Review, 94, 605-627. https://doi.org/10.1257/0002828041464605

Jiang, D. C., \& Xia, L. K. (2005). An Empirical Analysis of the Role of Foreign Direct Investment in Technological Innovation of China's High-Tech Industries. World Economy, No. 8, 5-12+82.

Kang, Z. Y. (2011). Export Trade and Independent Innovation-Empirical Research Based on Chinese Manufacturing Enterprises. International Trade Issues, No. 2, 35-45.

Li, X. Z., \& Zhang, X. D. (2008). Analysis of the Impact of Foreign Direct Investment on China's Technological Innovation Capability and Regional Differences. China Industrial Economy, No. 9, 77-87.

Luo, J., \& Chen, J. G. (2014). Thresholds for R \& D Input, Foreign Direct Investment and China's Innovation Ability: A Test Based on Threshold Effects. International Trade Issues, No. 8, 135-146.

Luo, W., \& Ge, S. Q. (2015). Entry of Multinational Corporations and China's Independent R \& D: Evidence from Manufacturing Enterprises. World Economy, 38, 29-53.

Nie, H. H., Tan, S. T., \& Wang, Y. F. (2008). Innovation, Enterprise Scale and Market Competition: Analysis of Panel Data Based on Chinese Enterprise Levels. World Economy, No. 7, 57-66.

Liu, C. L., Kang, M. N., \& Qiu, L. C. (2018). Foreign Capital Entry and Profit Rate of Domestic Enterprises: Evidence from Chinese Manufacturing Enterprises. World Econo$m y, 41,98-120$.

Qiu, B., Yang, S., \& Xin, P. J. (2008). Research on FDI Technology Spillover Channels and China's Manufacturing Productivity Growth: An Analysis Based on Panel Data. World Economy, No. 8, 20-31.

Tong, G. M., \& Yan, B. (2005). The Spillover Effect of FDI on China's Innovation Capacity. World Economy, No. 10, 18-25+80.

Wang, Z. P., \& Li, Z. N. (2003). Research on the Impact of Foreign Investment on the Production Efficiency of Chinese Industrial Enterprises. Management World, No. 4, 17-25.

Wang, H. L., Li, D. K., \& Feng, J. X. (2006). FDI and Independent Research and Development: Empirical Research Based on Industry Data. Economic Research, No. 2, 44-56.

Wang, H., Lai, M. Y., \& Tong, J. Y. (2010a). Research on International Technology Transfer, Heterogeneity and Technology Innovation of Chinese Enterprises. Management World, No. 12, 131-142.

Wang, R., Yan, B., \& Deng, W. G. (2010b). The Impact of FDI on China's Industrial Independent Innovation Capability and Its Mechanism-Based on the Perspective of Industrial Association. China Industrial Economy, No. 11, 16-25.

$\mathrm{Wu}, \mathrm{Y}$. B. (2012). Which Ownership Type Enterprise in China Is the Most Innovative? World Economy, 35, 3-25+28-29+26-27. 
Wang, P., \& Zhang, J. B. (2012). Foreign Direct Investment, Regional Differences and Scale and Level of Innovation: An Empirical Study Based on Panel Data of Nine Provinces in the Mainland of the Pan-Pearl River Delta Region. International Trade Issues, No. 12, 84-94.

Xing, F., \& Zhang, J. H. (2009). Impact of Foreign Technology Transfer on China's Independent R \& D. Economic Research, 44, 94-104.

Zhang, J., Liu, Z. B., \& Zheng, J. H. (2007). Research on the Key Influencing Factors of Innovation Activities of Chinese Manufacturing Enterprises-Analysis Based on the Questionnaire of Manufacturing Enterprises in Jiangsu Province. Management World, No. 6, 64-74.

Zhang, H. Y. (2008). The Impact of Foreign Direct Investment on the Independent Innovation Ability of China's Industries-A-Discussion on the Determinants of Independent Innovation. International Trade Issues, No. 1, 72-81.

Zhang, J., Lu, Z., Zheng, W. P., \& Chen, Z. Y. (2012). Financing Constraints, Financing Channels and Enterprise R \& D Investment. World Economy, 35, 66-90. 